\title{
PREFACE
}

\section{Experimenting with the Hermitage}

$\mathbf{T}$ his book results from a series of experiments. The first and foremost of these experiments is the collaboration between a scholar, foreign to Russia until 2012, and the director of a tight and proud community-the "Hermitagers"solidly attached to their institution. Feeling a foreigner to Russia during the period 2012-2015 came easily. Nationalist sentiment spared no quarter of the country. Russian academia was trapped in the absurd choices required by the growing tensions following the escalation of the feud between the West and Moscow in the wake of the Ukrainian operations. I was a strange foreigner: a caricature of a foreigner because I started this project with a limited command of Russian, and because I was coming with the mixed aura of a few years as an assistant professor at MIT and the much greater aura of the "French social scientist." The aura was different than what Anglo-American scholars have discerned in French social scientists. It was colored by the idea that Saint Petersburg was once closer to Paris than to Moscow and that many French (or French speaking and writing) philosophers traveled to the Winter Palace to advise its residents. In the eighteenth century, Denis Diderot and Joseph 
de Maistre both cemented close intellectual relations through grand principles and lofty generalizations-as Diderot himself recognized, when he famously wrote that the first time he had felt a free man was in Russia, a country where men are called slaves.

In the face of self-assured and self-confident employees of a Russian institution, my combined professional and personal identities were slippery enough that I surprised my interlocutors. Why would a foreigner, unable to express himself and his most basic research needs, come to a closed institution with the claim to study it in original ways? Others before me had tried and failed to penetrate Russia. Most recently, French architect Dominique Perrault had won-and then lost-the competition for the new Marinskii Theater in a turn of events that had left both sides bitter and in conflict. And the conversation leading to this study started in September 2012, exactly two hundred years after Napoleon's disaster at Berezina. So, the prospect of a French scholar exploring Russia and being either overwhelmed or routed out did not escape my interlocutors. Nevertheless, being French was also an immense asset when I started interviewing Hermitagers in the museum: one of their claims is to be both the guardians of the treasures of Russia, with its many complex layers, and to be its most European avant-garde. Conducting this study as a French social scientist eased my conversations with older employees, who likely would have found it degrading to be questioned by an American scholar, let alone a "technologist" from Massachusetts. I noted their impeccable command of the French language and their reminiscences of famous French novels: a Frenchman, they seemed to believe, was likely to possess a similar understanding of the sophistication of Russia. Younger employees were less charmed by French etiquette than they were curious about the trajectory of a Parisian, once stranded on the American East Coast for a decade, traveling back too far east in Old Europe. These probes and assessments went on for the duration of the project, but the Hermitagers' claim for the uniqueness of the museum never disappeared, and as that claim persisted, so too did my experience of being a foreigner. That experience was shared by even my 
most staunchly Russian colleague, who insisted that the museum was impenetrable for everyone, let alone an outsider.

I had not at first relocated to Saint Petersburg to study the museum. I had come by invitation of the rector of the European University at Saint Petersburg. Oleg Kharkhordin had launched a new Center for Science and Technology Studies in 2011, and he was looking for a director. After a week in Saint Petersburg, I met with Mikhail Borisovich Piotrovsky, the director of the State Museum Hermitage, who was visiting the university in his capacity as head of its board of trustees and instructor in art history. The conversation was as brief as it was consequential: being asked what I studied, I decided to cover my growing sense of hesitation in the face of many possible projects in my new home: "I study objects" was my strategically vague reply. Firm and decisive, the director of the museum determined that only the most improbable choice-an inadequate and illiterate scholar-held out the possibility of mining insights from his institution. This decision, sealed during the cocktail hour opening the joint Hermitage-National Gallery exhibition of medals depicting Napoleon, would lead to this book. It was to be neither a journalistic piece in search of juicy little stories of the Hermitagers nor a consultant's report on the museum's own efficiency. 



$$
\begin{aligned}
& \text { ART OF } \\
& \text { MEMORIES }
\end{aligned}
$$


